\title{
The Psychological Advantages of Enhanced Sensitive Attunement Through Nappy-Free Elimination Communication
}

\author{
Miranda Thorpe \\ Registered Psychotherapist, Psychotherapy at Apollo, Auckland
}

\begin{abstract}
The emotional and environmental impact of transitioning from a nappy-free culture to a society dependent on disposable nappies comes at a cost. After a seven-month "baby observation" travelling through Asia, my hypothesis is that the traditional indigenous method of managing the baby's elimination enhances attunement, bonding, and attachment, and when the child feels held in mind by the mother in this way he is more emotionally regulated and somatically connected. However, the exponential use of disposable nappies may be our blind spot where neither the dangers to the psychological and physical health of the future generation, nor to the planet, are being held in mind.
\end{abstract}

\section{Waitara}

He utu ka tau ki te taha kare-ā-roto, taha pūtaiao mai i te whakawhitinga i tētahi ahurei kope pātea ki tētahi hapori whakamau kope whiu. I muri mai i te mātakitakinga kōhungahunga i te haerērētanga i Āhia, e whakapae ana au nā te tikanga whakahaere whakaputa para a te kōhungahunga ka hōhonu kē ake te piri te pirihonga,ā, inā rongo te tamaiti i te pēnei o tōna mau ki tōna whāea ka mauri tau ake te atoato. Heoi anō, ko te mahi tautokonga mau kope whiu pea tō tātou whakapuranga kanohi inā te kore e whakaaro ake ki ngā tūpatonga ki te oranga hinengaro oranga tinana ki ngā rēanga o anamata, tae atu hoki ki a Papatuanuku.

Keywords: Elimination Communication; disposable; nappy; attunement; indigenous; mentalization; somatic; environment

Thorpe, M. (2014). The psychological advantages of enhanced sensitive attunement through nappyfree Elimination Communication. Ata: Journal of Psychotherapy Aotearoa New Zealand, 18(2), 127-139. DOI:10.9791/ajpanz.2014.12 (C) New Zealand Association of Psychotherapists Inc. 


\section{Introduction}

My interest in this issue began during a 2007 visit to Bali when I observed how effortlessly the mothers managed the ablutions of their very young babies who only wore cotton shorts without any form of nappy. I was also struck by Balinese relational ease, their depth of connection with their babies and children, with one another, and with us. I wondered if their close body contact with their babies, and the manner in which they trained them so early, had any bearing on their attachment styles. Just five years later I was shattered to see dirty disposables in the rivers. What was happening to this beautiful island? I decided to investigate. Firstly, how did mothers in Eastern countries raise their children without nappies and potty train them so young and, secondly, was there a trend towards abandoning this traditional method? Throughout a seven-month backpacking exploration in South East Asia and the Indian subcontinent I conducted 73 interviews with parents. I will refer to the caregiver as female and the baby as male for grammatical ease but in no way is this intended to be disrespectful. This article is the story of my evolving curiosity, observations and concluding reflections.

After that first trip to Bali I began paying attention, noticing that New Zealand mothers potty train their children at three or four years, and that disposable nappy advertisements show children older than toddlers wearing disposables. I recently saw a British newspaper headline regarding the NHS tackling the increasing number of children starting school still in nappies (Day Nurseries, 2013). Local supermarkets promote a plethora of disposable nappies for newborns, crawlers and toddlers, and for swimming. I see nappies that ensure a "dry" feeling for "up to 12 hrs", Learner nappies that ensure a "wet" feeling, "learner" Pull Ups, and I was shocked to see night nappies for four to 15 year-olds! I wondered about the aetiology of what I considered prolonged nappy use. I had raised my six children from 1976-87 with cloth nappies, and by 1987 the disposable nappy had evolved into an occasional luxury. I potty trained all of them from 18-24 months, depending on the season and temperament of the child, but blindly never considered alternative indigenous methods.

Researching the internet revealed a whole new world 25 years on with sites on the ecological "war" between cloth and disposables (Global Industry Analysts, 2008), a few on the health dangers of using disposables, and even fewer on the technique of "Elimination Communication" which I discovered was the Western term for the technique of heightened attunement that had so struck me in Bali. Interestingly, Attachment Parenting does not take a stance on Elimination Communication, concentrating instead on breast feeding, co-sleeping, and sling use. What I found most striking in all the literature was the absence of discussion, let alone emphasis, on the psychological, emotional, and relational benefits of using this indigenous "natural infant hygiene" method (Bauer, 2006).

\section{Environmental Dangers}

There is certainly a growing environmental problem. It was calculated that 342 million disposables were used on one day, 25 January 2012, despite only $21 \%$ of the world's population using them. A number of the world's countries have over $90 \%$ market 
penetration with the United States, the United Kingdom, and New Zealand being virtually saturated. However, in China market penetration is only $16 \%$ and in India it is two per cent (Landmark Consultancy Group, 1991). Research highlights the growth of this oildependent industry, the countries being targeted, and the enormous financial profits being made by the manufacturers of disposables (Richer, 2012).

In the US, on average, the child potty trained at 30 months uses 10,000 disposable nappies costing about NZ\$4,000. Last year, in the US alone, 27.4 billion disposables were used. Laid out as a path, these nappies would stretch to the moon and back nine times every single year. It is estimated that a disposable nappy takes at least 550 years to decompose in a landfill, where they are currently the third largest consumer item. Five million tonnes of untreated human waste is put into the landfills annually, contaminating the ground water and spreading disease (Environmental Protection Agency, 2012). Advice from the American Public Health and Pediatric Societies is included on some disposable packages urging parents to dispose of any faecal matter into the toilet first, but I have never seen a parent do this.

\section{Health Dangers}

With one million disposables used daily in New Zealand, the dangers to our immediate environment are obvious. Less well advertised are the potential physical dangers to our offspring. The thin disposable used currently has a polyacrylic acid core of small beads that swell to 100 times their weight, and consequently are able to hold a great deal of urine and faecal moisture. One nappy company advertises that their disposable allows the baby to feel dry for "up to 12 hours", all the time accumulating a heavy weight that hangs between his legs on his soft bones. Disposables now are almost entirely made up of polyacrylic acid beads, polyacrylate, polypropylene, polyester, polyethylene, synthetic rubber, and wood cellulose fibre. Some disposables in this self-regulating industry contain carcinogenic dioxins and tribulytin (Environmental Protection Agency,1990). Studies on toxic chemical absorption through a baby's delicate skin are still embryonic. The very same polyacrylic acid was used in tampons in the 1980 s and discontinued after it was found to cause potentially fatal Toxic Shock Syndrome. Some studies suggest that babies exposed to disposables may have a greater propensity to asthma, bronchial and immunity problems (Anderson \& Anderson, 1999). A report from the disposable nappy industry shows that rashes rose from $7.1 \%$ to $61 \%$ during a randomised controlled trial (Landmark Consultancy Group, 1991), and lawsuits against Procter \& Gamble (Dry Max Pampers) and KimberleyClark (Huggies) have recently been upheld (Reuters, 2011). A German study from Kiel University warns that male babies are subjected to hotter scrotal temperatures:

The fact that scrotal temperature is significantly increased in male neonates, infants, and toddlers wearing modern disposable plastic lined nappies, and that the physiological testicular cooling mechanism is significantly blunted during plastic nappy use may have a negative long term effect on testicular maturation and spermatogenesis and, in addition, may facilitate the development of testicular cancer. (Partsch, Aukamp \& Sippell, 2000, p.3) 
The British medical journal The Lancet also warned of the potential dangers of hip dysplasia in babies who use disposables (Dezateux \& Rosendahl, 2007), However, overall I found remarkably few studies assessing the risks to babies who wear disposable nappies.

In addition, rarely have I heard about the dangers of delayed toilet training, yet studies reveal that there are many, including children being at high risk of developing serious bladder infections, constipation, enuresis, and delayed sphincter control (Parenting Science, 2010).

...nowadays there is a number of children with stipsis, enuresis and with very late control of their sphincters. In the past it was not like this. It has been demonstrated in some studies that we know for sure that if you start later you might have serious problems. For example, stool toileting refusal is 20 per cent if you start around two years of age. If you start between 42 months and 48 months, you have a risk of about 50 per cent. If you start around four years, the risk is about 73 per cent. (Rugolotto, 2006)

Rugolotto (2006) asserts that incontinent children are more likely to have begun potty training after 30 months. While this is obviously a problem for the children and their parents, it is yet another marketing opportunity for the disposable nappy industry.

\section{Elimination Communication and the Psychological Implications}

So what is the alternative? In the West the standard answer is to use cloth. This enables the baby to feel the consequences of his elimination and thus he is ready to be potty trained earlier. Also, using cloth nappies is more labour intensive for the mother so she has an incentive to potty train earlier. However, the parents I interviewed in Asia preferred to use Elimination Communication at home with the use of the occasional disposable during outings. Elimination Communication is the Western name for a specific indigenous and traditional technique of potty training that relies on minute, careful observation of the newborn's pattern of eliminating body waste. It is a practice in which the caregiver uses intuition, timing, signals, cues, and associations to address a young baby's need to eliminate. The focus is on attunement to the newborn's innate rhythms, just as with feeding and sleeping, with careful observation of when the baby eliminates. A newborn urinates approximately every 10 minutes, a six month old about every 20 minutes. The mother has to be totally attuned to the baby's unique body language and habits, when his body indicates he is about to eliminate and she begins to anticipate his intentionality. She will then hold the young baby in a certain position over the basin, toilet, potty, or outside and patiently wait until he urinates or defecates. At this point the mother then uses cueing by making an onomatopoeic sound when the baby urinates and a different or the same sound when he defecates. The baby starts to associate that position and sound with his body waste's elimination.

The optimal window of opportunity for mother and baby to be attuned to one another is from birth to four months as the baby is not mobile and eliminates frequently so there 
is more opportunity for learning. At this stage the baby also learns very quickly. However, Elimination Communication can happen at any age, and can be practised full-time, or just during weekends, on evenings, or occasionally with a particular caregiver i.e., grandmother or nanny.

In a similar way the therapist focuses on the client's patterns; what is important is the therapist's detailed, attuned, and careful observation of the client's "output", together with the holding of the client in mind. The therapist's interested attention in and attunement to the client's conscious and unconscious "elimination" in the form of words and body language is essential for a good therapeutic connection. Therapist and client are also constantly learning from each other.

The mother and child have an additional advantageous portal to early body connection through Elimination Communication. The newborn baby's universe is centered on his sensations; he experiences his skin and body as an extension of the self, and this forms a powerful link between his body sensations and his mother's unconscious. My hypothesis is that if the mother holds the baby in mind, the baby feels held in mind, and is then able to hold himself in mind. I believe that the child has a stronger connection to his physical and psychological self, and that this in turn leads to his enhanced ability for affect regulation. Mother follows baby and baby follows mother in a dance of conscious and unconscious emotional, somatic, and relational communication.

It is worth asking the question as to whether early potty training can cause physical or emotional problems. Studies conclude that it does not (Parenting Science, 2010). However, coercive potty training does, regardless of the age of the child. Of the utmost importance is a benign, accepting attitude towards the child's elimination. Freud was concerned about any approach to toilet training that might be regarded as extreme "too early, too late, too strict, too 'libidinous'” (Fenichel, 1945, p. 305). In addition, he did not link early toilet training to personality disorders (Fisher \& Greenberg 1977; Masling, 1999). The coercive and punitive training of the 1920 and 1930 s was conflated with early training, so post-World War II medical reformers swung the other way. However, the few studies that have explored gentle early training show no resulting behavioural problems or negative side effects (Ball, 1971; Smeets et al, 1985). In addition, studies confirm that early training helps prevent urinary tract infections (Jason et al 2000; Sillen \& Hanson, 2000) and some research specifically recommends it (Hellstrom \& Sillen, 2001). Also how the mother reacts to the baby's excreta is important. In the East, everybody I interviewed was relaxed and light hearted in relation to baby excreta, in stark contrast with the sanitising West where a baby's body fluids are often referred to as dirty or disgusting. Surely this aversion must have a conscious and unconscious effect on a child if he is perceived as a germ spreading, soiling contaminator? If the caregiver reacts with negativity to what the baby cannot control, but is a part of him, an extension of his body, the child cannot but shamefully internalise this reaction as him being "bad".

Whilst traveling I also noticed there was more skin to skin contact, presumably providing both mother and baby with oxytocin, a "feel good chemical”. Nils Bergman's "Kangaroo Care" study in Cape Town demonstrated that mothers carrying their premature babies strapped to their bodies, skin to skin, was essential to the baby's brain development (Bergman, 2005). In the East, the need for the mother's proximity is 
constantly emphasised. Lewis et al well described the impact of the mother mouse's absence on the baby mice's failure to thrive despite the nest environment being maintained with food and warmth. "The mammalian nervous system depends for its neurophysiologic stability on a system of interactive coordination, wherein steadiness comes from synchronization with nearby attachment figures ... We call this mutually synchronizing exchange limbic regulation" (Lewis, Amini, \& Lannon, 2000, p. 85). The endemic practices in Asia of breastfeeding, co-sleeping, and sling use ensure that babies are well cared for, but I wonder about our Western emphasis on a baby's need to develop separation, individuation, autonomy, self-sufficiency, and independence.

As the nervous system matures, a baby reclaims some regulatory processes and performs them autonomously. Even after a peak parenting experience, children never transition to a fully self-tuning physiology. Adults remain social animals: they continue to require a source of stabilization outside themselves...people cannot be stable on their own - not should or shouldn't be, but can't be...Stability means finding people who regulate you well and staying near them. (Lewis, Amini, \& Lannon, 2000, p. 86)

In the West, we have a huge amount of infant paraphernalia that cannot but prevent skin contact between mother and baby; cribs, cots, car capsules, baby bouncing chairs, "Jolly Jumper", formula bottles, walking rings, car seats, prams, strollers, playpens, high chairs, separate beds, and separate rooms. During the seven months of my research project I saw only three strollers. The babies were constantly held in the embrace of parents, grandparents, family, and friends. A Montreal study found that babies carried by their mothers for more than three hours per day, cried and fussed 51\% less during the evening hours (Hunziker \& Barr, 1986). In Bali, until the local priest performs a ritual when the baby is three months old, the child cannot touch the ground so has to be constantly carried. Throughout Asia the child sleeps in the parents' bed, or in a hammock above their bed, suckles on his mother's breast (sometimes for two or three years), her hand feeds him his first solids, and his father carries him as he grows. The baby moves from a sling, to a lap, to a hip, to shoulders, to a crowded motorbike - a continuous relay of skin, touch, and human embrace.

The need for an attuned early environment is well documented. Stern's (1985) definition of attunement is a natural empathic responsiveness between two individuals that subtly conveys a shared emotion. Attuned adults will be able to acknowledge the infant's current emotional state and symbolise it in verbal and non-verbal interaction. These attuned interactions help the infant develop emotional regulation. Allan Schore emphasises the importance of early right brain connection with the mother.

In his 2001 paper, Schore describes in detail the neurobiology of a secure attachment. He contends that attachment theory is in essence a regulatory theory and that the mechanism through which the baby's brain develops is through the millisecond-to-millisecond reciprocal interaction. As the synchrony is established, the baby's arousal level is regulated. Both containment and reciprocity are involved. (Douglas, 2007, p. 20) 
The issue of psychological containment and holding is fundamentally important. I believe that the mother practising Elimination Communication, who has to be so finely and minutely attuned to her baby's body cues, is optimally attached in a relational sense with her baby, at a conscious and unconscious level. My sense is that this in turn influences the child to be more aware, sensitive, and connected to his own body, to his internal world, and thus more relationally connected to others. This mother holds her newborn baby in mind in a particularly acutely attuned detailed manner that contains him, leading to reciprocity, fostering his ability to mentalize, and heightening his somatic sensitivity. The evidence shows that the early experience of being closely held in mind by the mother affects the child's capacity for empathy and mentalization. Fonagy and colleagues' notion of mentalization and reflective function is central to my argument.

More recent research has also highlighted the importance of the maternal reflective function and the capacity of the parents to experience the baby as an "intentional" being (emphasis in original) rather than simply viewing them in terms of physical characteristics or behaviour. This is what helps the child to develop an understanding of mental states in other people and to regulate their own internal experiences. (Fonagy, 2002, p. 404)

The opposite is the worst case scenario: the baby is neglected and abandoned, with an emotionally absent, isolated, depressed mother who is herself neglected and abandoned by society. Or the baby is left in day care with rotating, transient, disconnected carers, formula-fed by a propped up bottle, neglected with no skin contact. As Winnicott (1974) points out it is the absence of what could have been that produces the "greatest scar". A baby left to his own devices for hours in the same disposable nappy has a similar experience. He is conditioned for years to evacuate into an ever-dry false nappy, belying the child's true body state, so that he feels dry when he is actually wet. This is a fundamental betrayal, a breach in the basic stage of trust. This betrayed child does not connect his actions with consequences; he is ignorant of his own body sensations, and himself. My concern is that the disposable nappy is increasingly becoming the maternal "holder" and "container", affecting attachment styles, and impacting on the future generations' ability to relate to the body, the self, another person, and the community. If these neglected people are later able to access psychotherapy, these clients would expect the psychotherapist to be the "nappy" that holds all the "crap", into which they evacuate and "dump". The task would be to gradually introduce the notion of connection, relationship, and consequence. As Bion (1962) suggested, the effective psychotherapist takes on board the powerful feelings of another and, by communicating with thought, gesture, and speech, makes them more manageable. Ideally, the therapist would process and return beta elements to these clients in a more manageable alpha form, To continue the analogy, the therapist would need to be the "waste processing plant".

\section{Observations and Reflections}

My initial paper at the Asia Pacific Rim International Counselling and Psychotherapy Conference in August 2013 in Sarawak, Malaysia, was greeted with an enthusiastic response from delegates who invited me to their universities and other institutions to 
raise awareness of the current erosion of traditional Elimination Communication. I also intend completing a documentary film.

The mothers and other caregivers I interviewed over the seven months were from Bali, Lombok, Burma, Thailand, Laos, Vietnam, Cambodia, Malaysia, India, Sri Lanka, and Maldives. Recurrent interviewee phrases of note were "You have to do the best for your baby." "Pampers are not good for the baby's skin, they get red points." "The doctor said not to use Snuggies." "Only a lazy mother uses Pampers." "You have to pay great attention at the start, but then it is easy." "It's very simple." "It is more comfortable for the baby."("Pampers" and "Snuggies" were common euphemisms for any brand of disposable nappy.) All interviewees started the observation stage of Elimination Communication in the first few weeks after their baby's birth and introduced the potty at varying months in the first year. Although some reported that their babies were toilet trained well before 12 months, it was universally reported that all the babies were toilet trained and nappy-free during the day by 12 months. Many said their babies were also dry at night by 12 months.

It seemed to be predominantly the mothers and grandmothers who were in charge of the newborns, with fathers and grandfathers increasingly participating after the initial months. Mothers very much set the frame and structure, like their psychotherapist counterpart, providing greater emotional safety and freedom for the baby, or client. On the other hand, in the West, increasingly it seems that the baby leads and mothers follow, with mothers, I believe, having lost confidence in their own intuition. This is clearly seen in the potty training scenario. Repeatedly my interviewees deferred to grandmothers for child-rearing knowledge calling on a "vertical transmission" of elder experience. However, increasingly some of the younger generation are turning to their peers, gleaning information instead from a "horizontal" direction (Neufeld \& Mate, 2005).

Fathers and grandfathers were notably visible and interactive in the raising of their offspring. The modern Eastern family typically comprises a couple actively co-parenting with two children spaced apart by at least a couple of years, with grandparents supporting or raising the toddlers if the parents return to work. Supporting them is the extended family, the temple priests, and often the governments. A couple of Vietnamese interviewees told me that their Communist government gives good maternity leave, and when they return to work mothers start an hour later, return home at lunch to breast feed, and leave an hour earlier. There is an expectation that the government/community/parent supports the family to support the baby. "It takes a village to raise a child" is put into practice.

Expectations of indigenous babies' capabilities are also much greater. Repeatedly mothers told me "The baby learns very young from the parents" and "The little baby is very smart". Marten and Rachel de Vries from the Departments of Psychiatry and Anthropology, University of Rochester, New York lived with the Digo tribe of East Africa. Their noteworthy conclusions about indigenous child rearing practices and parental expectations were that "Mothers stated 'a baby is ready to learn' soon after birth, and expect a high degree of motor and social achievement at 3 to 5 months" and “... (mothers) stated that they initiated bowel and bladder training during the first few weeks of life and expected or had accomplished reasonable night and day dryness by 4 to 6 months" (1977,p.3). The mothers benignly expected their babies to be able to do this; the inference being that the expectations the mother held in mind for her baby were vital to what actually transpired. 
Many of the parents I interviewed also expected to feel somatic connections with their offspring. They reported feeling strong body sensations that resonated with their children's long after childhood; they "just feel it" in their bodies, "know" when their grown children need to eliminate, feel a somatic resonance when they are sick, and have many types of "inexplicable" body communications. This implies an unconscious and pre-verbal communication that begins and is fostered early in the dyad's relationship. The adults interviewed reported that their children, as well as their adult children, can describe their body sensations linked to their emotions in minute detail, conveying needs and discomfort unconsciously so that the parents intuit the communication. Maybe some Westerners would label this projective identification, intrusive, boundariless, and pathological enmeshment. However, good, nurturing secure attachment, as evidenced in the East, actually provides safety from these primitive defensive reactions. My impression was that people there chose to stay connected rather than needing to for defensive purposes.

Communal living was strikingly prevalent irrespective of differing ethnic, financial, religious, or educational circumstances. Families lived in close quarters in houses or compounds, with intergenerational dependence and respect. Spirituality, of whatever denomination, strongly connected communities, and although addictive consumerism of Western products was a growing force it seemed for now to sit alongside a time honoured valuing of family and ancestral traditions. Emigration had been reported as an impossible experience for some interviewees who had returned to their home country to be close to their families. The overwhelming majority of those interviewed reported a strong attachment to family, to living in close proximity, to being close, with a need to be physically and emotionally in touch. Close could mean adhesively attached, demanding, with little personal space, not necessarily benign, but notwithstanding that, it was certainly relational.

The industrial revolution in Europe precipitated radical change to our family systems; we must have used some form of Elimination Communication and been attuned in this way before the disruption of mass urbanisation. There were also disruptive waves of emigration and disconnection in families leaving for the New World. In the West, also in pioneering countries like New Zealand, we prize independence, stoicism, self-reliance, autonomy, and self-sufficiency, almost to the point of schizoid or autistic disconnection. Inter-personal dependence is often pathologised, but at what cost? Have we simply defensively repressed our yearning for deep connection with others? Here the child is often regarded as "strong" and "keeping it together" if he refuses to turn to others for help or connection.

Winnicott makes the good point that we need to develop the capacity for dependence before we can be truly independent. Perhaps true separation-individuation is paradoxically easier in cultures where dependence has been given the necessary time, attention, and containment. As one of my interviewees said, "You have to pay great attention at the start, but then it is easy". This echoes Bowlby's (1988) sentiment that when we have a child it is five years of investment of hard work but that this is an investment in preventing later problems. 


\section{Conclusion}

This research into Elimination Communication has highlighted an absence of integration of the disparate aspects of this issue, but most significantly it has revealed our blindness to its psychological and emotional importance. I am attempting to bridge the indigenous and Western worlds by shining a light on what up to now has been a blind spot. This is something that the East takes so for granted that we have disregarded and overlooked. Could this be one of the reparative missing links for the West's dysfunction? The mother who is so acutely tuned in to her newborn's bodily functions, in such a detailed and observant manner, must be linked, and seemingly is linked, at a deeply relational level for many years. From my continuous observations as an experienced psychotherapist over a period of half a year I conclude that this practice of Elimination Communication is the key ingredient: the mother-child relationship maintains that close conscious and unconscious psychological, emotional, and somatic connection that subsequently influences parental, familial, and community relationships.

What does an Eastern society lose with a transition to a more "Westernised" model of separation and disconnection; a colonisation of formula, disposable nappies, high chairs, playpens, strollers, crèche, and cars? I fear that the youth of the East are being seduced by these glittering symbols of status, the pseudo connection provided by social media, and losing their nugget of real gold. I believe that what people in the East currently take for granted is a vital intuitive and relational mothering skill that contributes towards individual and systemic deep connection. However, I worry that the traditional indigenous childrearing ways that have contributed to this very connection are being eroded rapidly, that the East is losing its capacity to hold its own cultural traditions in mind, and is blindly making a very valuable asset disposable.

\section{References}

Anderson, R.C., \& Anderson, J.H. (1999). Acute respiratory effects of diaper emissions. Archives of Environmental Health: An International Journal, 54(5), 353-358. doi: 10.1080/00039899909602500

Ball, T.S. (1971) Toilet training an infant Mongoloid at the breast. California Mental Health Digest, 9, 456-461. doi: 10.1007/s10151-007-0350-1

Bannon, M.J., Carter, Y. Practical paediatric problems in primary care. Oxford, UK: Oxford University Press.

Bauer, I. (2006). Diaper free! The gentle wisdom of natural infant hygiene. New York, NY: Plume Penguin.

Bergman, N. (2005). More than a cuddle: Skin-to-skin contact is key. The Practising Midwife, 8 (9), 29.

Bigelow, A.E., Littlejohn, M., Bergman, N., \& McDonald, C. (2010). The relation between early mother-infant skin-to-skin contact and later maternal sensitivity in South African mothers of low birth weight infants. Infant Mental Health Journal, 31(3), 358-377. doi: 10.1002/imhj.20260

Bion, W. (1962) Learning from experience. London, UK: Heinemann. 
Blum, N., Taubman, B., \& Nemeth, N. (2003). Relationship between age at initiation of toilet training and duration of training: A prospective study. Pediatrics, 111(4), 810-14. doi: 10.1542/peds.111.4.810

Boucke, L. (2008). Infant potty training: A gentle and primeval method adapted to modern living. Lafayette, CO: White-Boucke.

Bowlby, J. (1988). A secure base: Clinical applications of attachment theory. London, England: Routledge.

Clark, E. (2007). The real Toy Story: Inside the ruthless battle for America's youngest consumers. New York, NY: Free Press.

Day Nurseries (2013). NHS project tackles rising number of children starting school still wearing nappies. Retrieved from www.daynurseries.co.uk/news/article.cfm/id/1560948/innovativenhs-project-tackles-rising-number-of-children-starting-school-still-in-nappies

de Vries, M. \& de Vries, R. (1977). Cultural relativity of toilet training readiness: A perspective from East Africa. Pediatrics, 60, 170-177.

Dezateux, C., \& Rosendahl, K. (2007). Developmental dysplasia of the hip. The Lancet, 369 (9572), 1541-1552. doi: 10.1016/So140-6736(07)60710-7

Douglas, H. (2007) Containment and reciprocity: Integrating psychoanalytic theory and child development research for work with children. East Sussex, UK: Routledge.

Environmental Protection Agency, (1990). Integrated risk assessment for dioxins and furans from chlorine bleaching in pulp and paper mills. 560/5-90-011.

Environmental Protection Agency, (2012). Municipal solid waste generation, recycling, and disposal in the United States: Facts and figures for 2012. Retrieved from www.epa.gov/ epawaste/nonhaz/municipal/pubs/2012_msw_fs.pdf

Fenichel, O. (1945). The psychoanalytic theory of neurosis. New York, NY: Norton.

Fisher, S. \& Greenberg, R.P. (1977). The scientific credibility of Freud's theories and therapy. New York, NY: Basic Books.

Fonagy, P., Gergely, G., Jurist E.L., \& Target, M. (2002). Affect regulation, mentalization and the development of the self. London, UK: Karnac.

Global Industry Analysts (2008). Global market for disposable baby diapers to reach $\$ 26.6$ billion by 2012, according to a new report by Global Industry Analysts, Inc. Retrieved from www.prweb. com/releases/diapers_disposable/baby_infant/prweb1503344.htm

Gross-Loh, C. (2007). The diaper-free baby: The natural toilet training alternative. New York, NY: William Morrow.

Hann, M., Malan, A., Kronson, M., Bergman, N. \& Huskisson, R. (1999). Kangaroo mother care. South African Medical Journal, 89, 37-40. doi: 10.1002/14651858.CDoo2771.pub3.

Hellstrom, A.L., \& Sillen, U. ( 2001). Early potty training advantageous in bladder dysfunction. Decreases the risk of urinary infection (in Swedish). Läkartidningen, 98, 3216-3219.

Hopgood M. (2012). How Eskimos keep their babies warm: And other adventures in parenting (from Argentina to Tanzania and everywhere in between). New York, NY: Algonquin Books.

Hunziker, U., \& Barr, R. (1986). Increased carrying reduces infant crying: A randomized controlled trial. Pediatrics 77(5), 641-48.

Jason, U.B, Hanson, M., Hanson, E., Hellstrom, A.L. \& Sillen, U. (2000). Voiding pattern in healthy children o to 3 years old: A longitudinal study. The Journal of Urology 164(6), 20502054 . 
Landmark Consultancy Group (1991). A review of Procter e Gamble's environmental balances for disposable and re-usable nappies. The Consultancy.

Lewis, T., Amini F., \& Lannon, R. (2000). A General Theory of Love. New York, NY: Random House.

Masling, J. (1999). An evaluation of empirical research linked to psychoanalytic theory. Retrieved from www.psychomedia.it/rapaport-klein/masling99.htm

Neufeld, G., \& Mate, G. (2005). Hold on to your kids. New York, NY: Ballantine Books.

Parenting Science, (2010). The science of toilet training: What research tells us about timing. Retrieved from www.parentingscience.com/science-of-toilet-training.html

Partsch C-J., Aukamp, M. \& Sippell W.G. (2000). Scrotal temperature is increased in disposable plastic lined nappies. Archives of Disease in Childhood, 83, 364-368. doi: 10.1136/adc.83.4.364

Reuters, 2011. PeG settles Pampers Dry Max diaper-rash lawsuit. Retrieved from www.reuters. com/article/2011/06/13/procter-pampers-lawsuit-idUSN1311520120110613

Richer, C. (2012). Disposable diaper history. Retrieved http://disposablediaper.net/generalinformation/disposable-diaper-history/

Rugolotto, S. (2006). Potty whispering: The gentle art of infant potty training. (DVD) Lafayette, CO: White-Boucke.

Schore, A.N. (1994). Affect regulation and the origin of the self: The neurobiology of emotional development. New Jersey, NJ: Erlbaum.

Sillen, U. \& Hanson, E. (2000). Control of voiding means better emptying of the bladder in children with congenital dilating VUR. British Journal of Urology, $58(13), 1$.

Smeets, P.M., Lancioni, G.E., Ball, T.S., \& Oliva, D.S. (1985). Shaping self-initiated toileting in infants. Journal of Applied Behaviour Analysis, 18, 303-308. doi: 10.1901/jaba.1985.18-303

Stern, D.N. (1985). The interpersonal world of the infant. New York, NY: Basic Books

Winnicott, D. W. (1974). Fear of breakdown. International Review of Psycho-Analysis, 1, 103-107.

I obtained permission from all interviewees filmed during our travels.

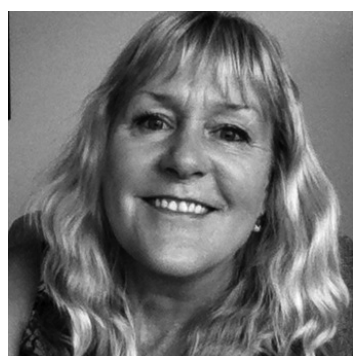

Miranda Thorpe works as a registered psychodynamic, psychoanalytic psychotherapist and supervisor in private practice with individuals, couples, families, and supervisees. She works in English, Portuguese, and French. She has specialist interests in issues of relationship difficulties, immigration, attachment, blended families, and abuse. A cofounder of Psychotherapy at Apollo in a pioneering integrated health and medical centre, she has been in private practice for 16 years. Miranda is registered, a member of the New Zealand Association of Psychotherapists with the Advanced Clinical Practice Certificate and is on the Admissions Committee. She is a member of the Psychoanalytic Psychotherapy Association of Australasia and of the International Association of Relational Psychoanalysis and Psychotherapy. Miranda has presented her papers and 
held workshops on immigration and attachment, as well as on the psychological and emotional advantages of Elimination Communication at national and international conferences. Born in England, Miranda was raised and has lived in numerous countries, before immigrating to New Zealand with her family 20 years ago. She had adult children and step-children, and young grandchildren. Contact details: kmal@slingshot.co.nz . 